\title{
Turisztikai célú támogatások jövedelmezőségi helyzetre gyakorolt hatásának vizsgálata az Észak- alföldi Régióban
}

\section{Monitoring of the profitability effect of tourism supports in the North Great Plain Region}

\author{
T. NAGY ${ }^{1}$,É. DARABOS ${ }^{2}$ \\ 1Debreceni Egyetem, Gazdaságtudományi Kar, Számviteli és Pénzügyi Intézet, nagy.tunde@econ.unideb.hu \\ 2Debreceni Egyetem, Gazdaságtudományi Kar, Számviteli és Pénzügyi Intézet, darabos.eva@econ.unideb.hu
}

Absztrakt. A turizmus a mai gazdaság egyik legnagyobb és legdinamikusabban fejődő ágazata, teljesítményének vizsgálata fontos kutatási terület. A szektor és vállalatainak teljesítménye szorosan összefügg, jelen tanulmány a vállalati oldalról történő teljesítményvizsgálattal foglalkozik. Pontos célja a 2007-2013. évi költségvetési időszakban juttatott turisztikai célú közösségi támogatások jövedelmezőségi helyzetre gyakorolt hatásának bemutatása az Észak-alföldi Régió két vállalatának példáján keresztül. A vizsgálat alapját a nyilvánosan elérhetô statisztikai, vállalati adatok, valamint a vállalatok által kitöltött kérdốivből, illetve a pályázati nyilvántartó rendszerükből származó adatok képezik.

Abstract. Today the tourism is one of the largest and the most dynamically progressive sector, monitoring of its performance important research area. The sector and its companies' performance are related tightly, a present study deals with the corporate performance test. Its accurate goal is the monitoring of the profitability effect of 2007-2013.yearly budgetary periods tourism supports in the North Great Plain Region through the example of two of a region's companies. The basis of the examination the statistical, corporate data which can be reached publicly and data from the questionnaire filled by the companies and data from their competition registrar.

\section{Bevezetés}

A turizmus a mai gazdaság egyik legnagyobb és legdinamikusabban fejődő ágazata, mindazonáltal egy meglehetősen új jelenség. Tudományos igényű vizsgálata csak a 20. század második felében kezdődött, mely kiterjedésének, struktúrájának és dinamikájának feltárását hivatott szolgálni (Leiper, 1993). Wilson és szerzőtársa szerint a turizmus, mint olyan nem is tekinthető önálló gazdasági ágazatnak, mivel homogén termékeket, szolgáltatásokat előállító vállalatcsoportként történő értelmezése nem lehetséges. Sokkal inkább tekinthető egy sajátos piacnak, ahol különböző ágazatok kínálata találkozik a turisztikai kereslettel (Kulendran-Wilson, 1989). Hasonlóan ehhez az állásponthoz Diamond sem tekinti egységes ágazatnak a turizmust, hangsúlyozza más ágazatokkal való kapcsolatát 
(Diamond, 1977). Belátható azonban, hogy ez a kapcsolat nem egyformán erős, a szálláshely szolgáltatás és a vendéglátás például szervesen kapcsolódik a turizmushoz és vannak olyan ágazatok, melyek szinte egyáltalán nem. A turizmus ágazatba tehát azok a tevékenységek tartoznak, melyek közvetlenül képesek hatást gyakorolni a turisztikai keresletre, illetve elsődleges céljuk ennek kielégítése. A turizmus ágazat úgynevezett „turisztikai alapszolgáltatásokat” foglal magába, mint például a szállásadás, míg a turizmus-gazdaság a turizmus multiplikáló hatását is figyelembe veszi, olyan, nem „alap” szolgáltatásokat is magába foglal, melyek csak közvetve kapcsolódnak a turisztikai kereslet kielégítéséhez. Elmondható, hogy a turisztikai szolgáltatások közé a szolgáltatások egyre szélesebb köre tartozik, gyakorlatilag minden olyan tevékenységet számításba kell venni, mely a turisztikai tevékenységgel összefüggésbe hozható szükségletek kielégítésére irányul.

Éppen ebből az összetettségből adódik, hogy a turizmus gazdasági teljesítményének számbavétele rendkívül bonyolult feladat. Jelen tanulmány nem is szándékozik a teljes ágazat teljesítményét vizsgálni, vállalati oldalról közelít meg egy jóval lehatároltabb témát. Cél a turisztikai célú támogatások jövedelmezőségi helyzetre gyakorolt hatásának vizsgálata 2, az Észak-alföldi Régióban működő vállalat példáján keresztül.

\section{A turizmus jelentősége az Európai Unióban, annak keresleti és kínálati oldala}

A turizmus hatása rendkívül sokrétü, interdiszciplináris jellegét Przeclawski már 1993-ban hangsúlyozta, véleménye szerint a turizmus egyszerre tekinthető gazdasági, társadalmi, kulturális, valamint pszichológiai jelenségnek (Przeclawski, 1993). Nem vitatható, hogy a turizmus hosszú távon mind a küldő, mind pedig a fogadó országok gazdaságában jelentős változásokat indukál. Kiemelendő azonban, hogy nem csak a turizmus hat a nemzetgazdaságra, a gazdaságban végbemenő folyamatok is visszahatnak a turizmusra.

A turizmus nemzetgazdasági jelentősége a két közvetlenül leginkább kapcsolódó ágazat, a szálláshelyszolgáltatás és vendéglátás teljesítményén keresztül mérhető közvetlenül. Hazánkban a szálláshelyszolgáltatás, vendéglátás bruttó hozzáadott értékkel mért teljesítménye 2013 óta folyamatosan növekszik, a legfrissebb 2016. évre vonatkozó adatok szerint 2016-ra jelentős, 7,2\%-os növekedés volt tapasztalható az előző időszakhoz viszonyítva, meghaladva ezzel a GDP átlagos növekedési ütemét. A turizmus alapágazataiban (szálláshely-szolgáltatás, vendéglátás, utazásközvetítés, -szervezés) összesen 27 ezer társas és 46 ezer egyéni vállalkozás működött 2016 végén. Ezek a vállalkozások összesen 193 ezer főt foglalkoztattak, az előző évhez viszonyítva 10 ezer fővel nőtt a foglalkoztatás ebben a szektorban (5,2\%-os növekedés), nemzetgazdasági szinten csekélyebb, 3,3\%-os növekedés volt tapasztalható $\left(I_{1}\right)$.

A turizmus jelentőségéről azonban nem csak nemzetgazdasági szinten van értelme beszélni, hanem az Európai Unió szintjén is. Az Európai Unió elismeri önálló gazdasági ágként a turizmust, ahogyan az a „Növekedés, versenyképesség és foglalkoztatás” címmel 1993-ban kiadott Fehér Könyvben szerepel, ugyanakkor a turizmus esetén érvényesül a szubszidiaritás elve, az EU nem vonta be a közösségi szinten szabályozott területek közé, hangsúlyozva nemzetgazdasági alapokon nyugvó jelegét. A 
tagállamok álláspontja meglehetősen eltérő ebben a kérdésben, a turisztikai piacot uraló fejlett országok, például a Benelux, Skandináv államok, vagy éppen Németország nem támogatják Unió szerepvállalásának fokozódását, ezzel szemben például a mediterrán térségben található kevésbé fejlett tagállamok az Unió beavatkozását szorgalmazzák. Teljesen érthető az álláspontjuk, hiszen az EU segítsége nélkül aligha lennének képesek behozni infrastrukturális lemaradásukat, mely nagymértékben gátolja turizmus-gazdaságuk, ezáltal nemzetgazdaságuk fejlődését.

Bár az Unió fejlesztéspolitikai stratégiájában nem jelenik meg a turizmus, mint kiemelt jelentőségű terület, az átfogó stratégiai célok elérését nagymértékben támogatja, jövedelmezősége fokozható, mulitplikativitás révén jelentős hatással van a teljes gazdaságra, a foglalkoztatásban betöltött szerepe sem vitatható. Az Európai Bizottság által 2006-ban kidolgozott, „Az EU új turizmus politikája: a partnerség erősítése az európai turizmus területén" című bizottsági közlemény jelentős hatással volt a turizmus további fejlődésére, középpontba került a tartós növekedés kérdésköre, és a turizmus fenntartható foglalkoztatásban betöltött szerepe. 2006-ben a turizmus jogilag az EU Bizottság hatáskörébe került, a lisszaboni szerződés azon ágazatok közé emelte, amelyek esetében a bizottságnak a szubszidiaritás és arányosság elveit figyelembe véve bizonyos hatásköre van, támogató, koordináló tevékenységet lát el. Célként fogalmazódott meg az Európai Unió, mint egységes turisztikai desztináció vonzóbbá tétele. 2010-ben a Lisszaboni Stratégia utódjaként megjelent az EU 2020 Stratégia, mely szintén feltételezi a turizmus növekvő szerepét.

\subsection{Keresleti oldal}

A keresleti oldal leginkább a turistautak számán keresztül ragadható meg. A legfrissebben elérhető statisztikai adatok a 2016. évre vonatkoznak, melyeket az 1. diagram szemléltet az EU-28 országokra vonatkozóan.

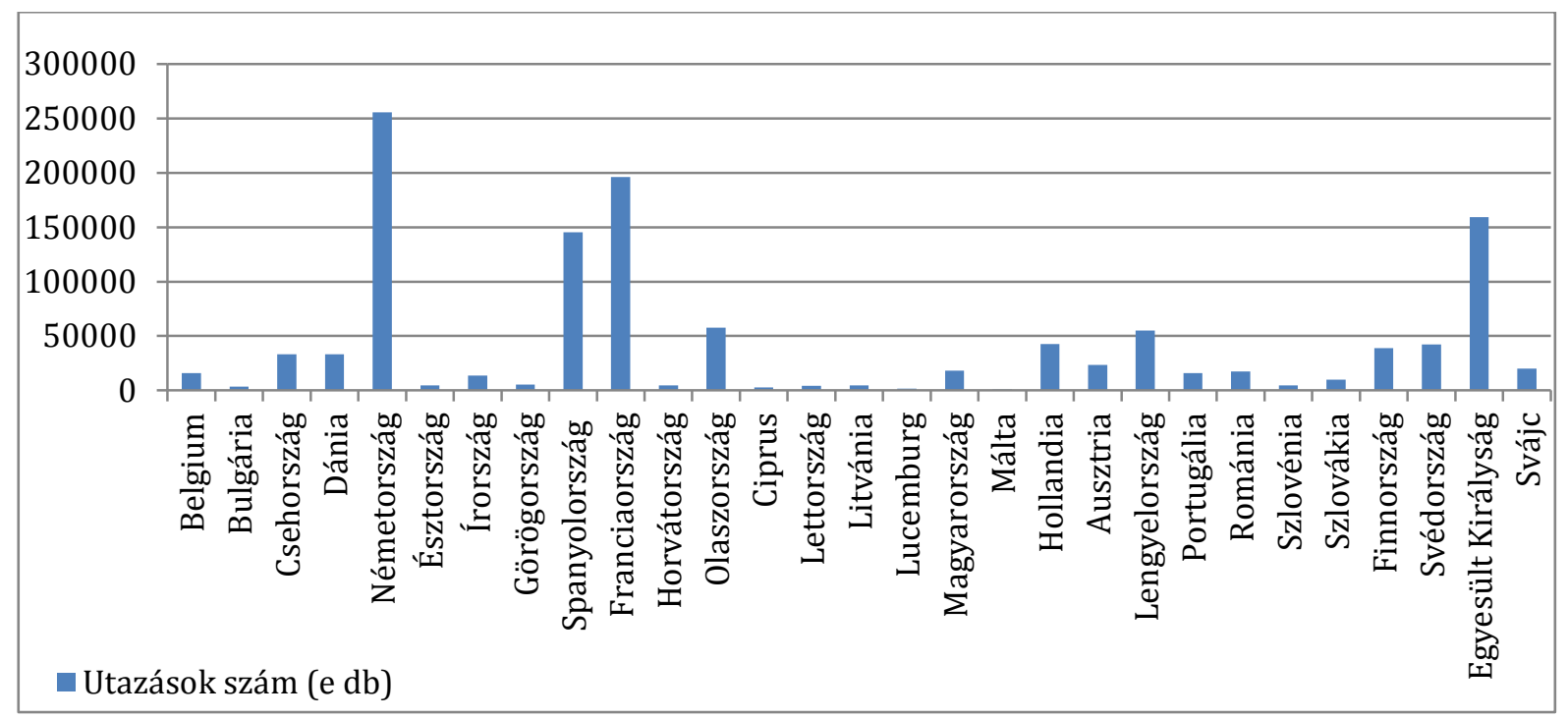

1. diagram: A turisztikai célú utazások száma az EU-28 országokban (15éven felüliek), 2016 Forrás: $\left(I_{2}\right)$ 
2016-ban csekély mértékben ugyan, de növekedett a turisztikai utazások száma az előző évhez viszonyítva. Ahogyan az az 1. diagramból jól látható az utazások nagy része, pontosan 61\%-ka 4 országra koncentrálódott. Németország részesedés meghaladta a 20\%-ot 255.648 ezer turisztikai célú utazással. Franciaország részesedése 16\%-os, mely 196.010 e utazást jelentett, ezt követte az Egyesült Királyság 13\%-os részesedése (159.414 e utazás), majd Spanyolország következett 12\%-kal (145.473 e utazás). Hazánkba, az Eurostat felmérései szerint 18.099 e turisztikai célú utazás történt, mely a teljes, Európai Unió országaiban történő 1.230 .339 e utazásból csupán 1,5\%-ot képvisel. Ha a rövid (maximum 3 vendégéjszaka) és a hosszú (4 vagy több vendégéjszaka) utazások arányát vizsgáljuk, Magyarország és Spanyolország kivételével arányuk megközelítőleg azonos, az említett két országban a rövidebb utazások aránya azonban magasabb, 70\% körüli. A turisztikai utazások megoszlása tovább vizsgálható az utazó nemzetisége alapján. A turisztikai utazások utazó nemzetisége alapján történő megoszlását a már korábban kiemelt 5 országra vonatkozóan az alábbi táblázat tartalmazza.

\begin{tabular}{|l|r|r|r|r|}
\hline \multirow{2}{*}{ Szempontok } & \multicolumn{2}{c|}{ Rövid utazások } & \multicolumn{2}{c|}{ Hosszú utazások } \\
\cline { 2 - 5 } Országok & $\begin{array}{c}\text { Belföldiek } \\
\text { aránya }\end{array}$ & $\begin{array}{c}\text { Külföldiek } \\
\text { aránya }\end{array}$ & $\begin{array}{c}\text { Belföldiek } \\
\text { aránya }\end{array}$ & $\begin{array}{c}\text { Külfföldiek } \\
\text { aránya }\end{array}$ \\
\hline Németország & $43,9 \%$ & $8,7 \%$ & $20,5 \%$ & $26,9 \%$ \\
\hline Spanyolország & $67,4 \%$ & $3,0 \%$ & $23,5 \%$ & $6,2 \%$ \\
\hline Franciaország & $49,6 \%$ & $3,2 \%$ & $38,4 \%$ & $8,8 \%$ \\
\hline Magyarország & $49,6 \%$ & $17,9 \%$ & $16,7 \%$ & $15,8 \%$ \\
\hline Egyesült Királyság & $49,9 \%$ & $6,6 \%$ & $17,3 \%$ & $26,2 \%$ \\
\hline
\end{tabular}

1. táblázat: A rövid és hosszú távú turisztikai utazások százalékos megoszlása az utazók nemzetisége alapján, 2016 Forrás: $\left(I_{2}\right)$

Az adott országba érkező teljes turisztikai utazásszámot tekintve látható, hogy a belföldiek által tett rövid utazások Franciaország, Magyarország és az Egyesült Királyság esetében 50\%-os arányt képviselnek, Németországban ez az arány 44\% alatti, Spanyolország esetében pedig majdnem 70\%-os. A külföldiek által tett rövidebb időtartamú utazások egyedül Magyarország esetében képviselnek jelentősebb, 18\%-os arányt. A külföldiek és a belföldiek hosszú távú utazásainak arányát vizsgálva pedig elmondható, hogy Németország és az Egyesült Királyság kivételével a belföldiek aránya magasabb.

\subsection{Kínálati oldal}

A kínálati oldalt pedig legegyszerúbben az aktív turisztikai szálláshelyek és a férőhelyek számával lehet jellemezni. 2015-ben az aktív turisztikai szálláshelyek száma meghaladta az 578 ezret az EU-28ban, melyek együttesen több mint 31 millió férőhelyet kínáltak. A rendelkezésre álló férőhelyek majdnem egyharmada két tagállamban, Franciaországban és Olaszországban összpontosult ( $\left.I_{1}\right)$. A 2016. évre vonatkozó adatokat a következő tartalmazza. 


\begin{tabular}{|l|r|r|r|r|}
\hline Mrszágok & $\begin{array}{c}\text { Kereskedelmi } \\
\text { szálláshelyek } \\
\text { száma (e db) }\end{array}$ & \%-os megoszlása & $\begin{array}{c}\text { Férőhelyek } \\
\text { száma (e db) }\end{array}$ & $\begin{array}{c}\text { \%-os } \\
\text { megoszlása }\end{array}$ \\
\hline Németország & 50152 & $8,2 \%$ & 3336 & $10,7 \%$ \\
\hline Spanyolország & 48701 & $8,0 \%$ & 5134 & $11,2 \%$ \\
\hline Franciaország & 30047 & $4,9 \%$ & 466 & $16,4 \%$ \\
\hline Magyarország & 4436 & $0,7 \%$ & 3944 & $1,5 \%$ \\
\hline Egyesült Királyság & 84580 & $13,9 \%$ & 31319 & $52,6 \%$ \\
\hline Összesen & 608400 & $35,8 \%$ & 516 \\
\hline
\end{tabular}

2. táblázat: A kereskedelmi szálláshelyek és a férőhelyek száma a korábban vizsgált Európai Uniós országokban, 2016-ban

Forrás: $\left(I_{3}\right)$

Az Eurostat 2016-ra vonatkozó adatai alapján a kereskedelmi szálláshelyek száma 30.400 darabbal, mint egy 5\%-kal bővült az EU-28 országaiban az előző évhez viszonyítva. A korábban, keresleti oldalról már vizsgált országokban a kereskedelmi szálláshelyek 35,5\%-a található, a legnagyobb részesedéssel az Egyesült Királyság rendelkezik. A férőhelyek számát tekintve jelentősebb növekedés nem történt 2015-höz viszonyítva, kiemelendő, hogy a vizsgált országok rendelkeznek az összes férőhely több mint $50 \%$-ával.

\section{A vizsgálat jövedelmezőségi mutatók, felhasznált adatok}

A jövedelmezőség mutatószámok képzésén keresztül vizsgálható, valamely eredménykategóriát viszonyítjuk egy kiválasztott vetítési alaphoz. Bármely számviteli eredménykategória alkalmas jövedelmezőség számításra, jelen tanulmány a legnagyobb súlyt képviselő üzemi (üzleti) tevékenység eredményét, illetve az adózott eredményt tartalmazó mutatókat vizsgálja. A vetítési alapok alapján beszélhetünk árbevétel arányos, tőkearányos, eszközarányos jövedelmezőségi mutatókról. A következő táblázat a vizsgált jövedelmezőségi mutatókat, illetve azok gazdasági tartalmát mutatja.

\begin{tabular}{|l|l|}
\hline \multicolumn{1}{|c|}{ Mutatók megnevezése } & \multicolumn{1}{c|}{ Tartalma } \\
\hline ROS (ÜTE) & ÜTE/Árbevétel+Egyéb bevétel \\
\hline ROS (Adózott eredmény) & $\begin{array}{l}\text { Adózott eredmény/Árbevétel+Egyéb bevétel+ Pénzügyi műveletek } \\
\text { bevétele }\end{array}$ \\
\hline ROE (ÜTE) & ÜTE/Saját tőke \\
\hline ROE (Adózott eredmény) & Adózott eredmény/Saját tőke \\
\hline & $\begin{array}{c}\text { 3. táblázat: } A \text { vizsgált jövedelmezóségi mutatók } \\
\text { Forrás: (Fazakas et al., 2009) }\end{array}$
\end{tabular}

Az árbevétel arányos jövedelmezőség (ROS) számításakor a kiválasztott eredménykategóriát viszonyítjuk a nettó árbevételhez és más bevételekhez, kiemelt figyelmet kell azonban fordítani arra, hogy csak olyan bevétel kategóriához hasonlítható az eredménykategória, amely hozzájárult az eredmény képződéséhez. Az árbevétel arányos jövedelmezőségi mutató megmutatja, hogy az bevételek hány százaléka realizálódik eredményként. A tőkearányos jövedelmezőségi (ROE) mutató 
arról ad tájékoztatást, hogy a vállalat milyen hatékonyan képes a tulajdonosok által a vállalakozás rendelkezésére bocsátott tőkét felhasználni az eredmény előállítása érdekében (Kondorosi, 2002).

Jelen téma megköveteli a vizsgált vállalatok minél nagyobb fokú hasonlóságát, nem csak számviteli adatokkal mérhető tekintetben (nagyságrendileg azonos mérlegfőösszeg és bevételek), hanem az igénybevett pályázatokra, illetve egyéb jellemzőkre vonatkozóan is. Mindkét vállalat az Új Széchenyi Terv Fejlesztési Program Észak-alföldi Operatív Programjának azonos prioritásához kapcsolódóan vette igénybe a támogatást. Az Új Széchenyi Terv célja a gazdaságélénkítés és munkahelyteremtés volt 2011-2013 közötti időszakra vonatkozóan. Hét kitörési pont fogalmazódott meg, (egészségipar, zöldgazdaság-fejlesztés, otthonteremtés, vállalkozásfejlesztés, közlekedésfejlesztés, tudományinnováció és foglalkoztatás), amelyek célja a foglalkoztatás bővítése, a gazdasági növekedés feltételeinek megteremtése, Magyarország versenyképességének javítása volt, kiemelt figyelmet fordítva a hátrányos helyzetű régiók felzárkózatására. ÉAOP keretén belül 132,6 milliárd támogatás került kiosztásra (I4). A 4. táblázat összefoglalva tartalmazza a vállalatok pályázati nyilvántartásiból származó felhasznált adatokat.

\begin{tabular}{|l|l|l|}
\hline \multicolumn{1}{|c|}{ Megnevezés } & \multicolumn{1}{c|}{ „A” vállalat } & \multicolumn{1}{c|}{ „B” vállalat } \\
\hline Fejlesztési program & Új Széchenyi Terv & Új Széchenyi Terv \\
\hline Operatív Program & ÉAOP & ÉAOP \\
\hline Érintett prioritás & Turisztikai célú fejlesztések & Turisztikai célú fejlesztések \\
\hline Konstrukció & $\begin{array}{l}\text { Szálláshelyek és szolgáltatások minőségi } \\
\text { fejlesztése }\end{array}$ & $\begin{array}{l}\text { Szálláshelyek és szolgáltatások } \\
\text { minőségi fejlesztése }\end{array}$ \\
\hline A projekt teljes költsége & $45.032 .300 \mathrm{Ft}$ & $53.423 .700 \mathrm{Ft}$ \\
\hline Támogatás összege & $20.264 .535 \mathrm{Ft}(45 \%)$ & $20.835 .243 \mathrm{Ft}(39 \%)$ \\
\hline Záró kifizetés dátuma & 2014.08 .15$. & 2014.10 .13$. \\
\hline
\end{tabular}

4. táblázat: A vállalatok pályázati nyilvántartásából származó adatok

Forrás: (Vállalati belső nyilvántartások)

Jól látható, hogy a vállalatok nagyságrendileg hasonló költségvetésű (45.032.300 Ft és 53.423.700 Ft) projektet valósítottak meg, közel azonos (20.264.535 Ft és 20.835.243 Ft) támogatási összeg igénybevételével. azonos időszakban a Szálláshelyek és szolgáltatások minőségi fejlesztése konstrukción belül. A támogatási intenzitás „A” vállalat esetén 45\%-os, míg „B” vállalat esetén 39\%-os volt, azaz „A” esetben a teljes költség 45\%-a, „B” esetben pedig a teljes költség 39\%-a támogatásból került finanszírozásra.

További egyezőség, hogy a vállalatok nemcsak azonos régióban, hanem azonos településen, Hajdúszoboszlón üzemeltetik szállodájukat. $\mathrm{Az}$ Észak-alföldi régió turisztikai zászlóshajója vitathatatlanul az egészségturizmus, melynek vizsgálatával számos kutatás foglalkozott (Könyves et al., 2005; Müller-Könyves 2004; Könyves-Müller 2007; Kerényi et al., 2010a). A hazai fürdőkutatások (Müller-Kórik 2009; Könyves et al., 2004; Mosonyi et al., 2013) igazolták, hogy az Észak-alföldi Régió fürdői az egészségturisztikai kereslet egy fontos desztinációját képviselik, amelyek közül a hajdúszoboszlói az egyik piacvezető fürdő hazánkban, melyhez igen magas vendégelégedettség társul.

Más régióban végzett fürdőkutatások (Kerényi et al., 2010b; Barta et al., 2011; Müller et al., 2016 a,b) igazolták, hogy a fürdők, mint turisztikai attrakciók meghatározó elemei a régió turisztikai 
kínálatának. A turisztikai márkakultatások szerint a hajdúszoboszlói fürdő igen erős és kiforrott márkaalkotókkal rendelkezik, mely a hazai és nemzetközi egészségturisztikai piacon is versenyképes attrakció. Hajdúszoboszló, mint a régió egyik vezető egészségturisztikai desztinációja, mely a kutatásom hátterét adja, befolyásolhatja a kapott eredményeimet.

A már említett adatokon kívül egyéb, hatásvizsgálati kérdőívből származó adatokat az 5. táblázat tartalmazza.

\begin{tabular}{|l|l|l|}
\hline \multicolumn{1}{|c|}{ Megnevezés } & \multicolumn{1}{|c|}{ „A” vállalat „B” vállalat } \\
\hline A megvalósított beruházás célja & $\begin{array}{l}\text { Éttermi szolgáltatás színvonalának } \\
\text { emelése }\end{array}$ & $\begin{array}{l}\text { Éttermi szolgáltatás színvonalának } \\
\text { emelése, wellness részleg fejlesztése }\end{array}$ \\
\hline Beruházás kezdete & 2014 & 2014 \\
\hline Üzembe helyezés & 2015 & 2015 \\
\hline Felvett hitel összege & $20.000 .000(44 \%)$ & $5.000 .000(9 \%)$ \\
\hline A hitel futamideje & 10 év & 3 év \\
\hline A hitel THM-je & $11,70 \%$ & $7,20 \%$ \\
\hline Bevételek és ráfordítások tevékenységenkénti megoszlása a vizsgált időszakban (2015-2017)
\end{tabular}

5. táblázat: Hatásvizsgálati kérdőívből származó adatok

Forrás: (Saját készítésü kérdőív)

$\mathrm{Az}$ „A" vállalat célja a beruházás megvalósításával az éttermi szolgáltatás fejlesztése, míg a „B” vállalat az éttermi szolgáltatás színvonalának emelése mellett a wellness részleg fejlesztését is célozta. A wellness részleg fejlesztése az eredmények értelmezésében kulcsfontosságú. A wellness kínálati elemek iránt egyre növekvő keresletet tapasztalunk az egészségtudatos életmód terjedésével. A wellness kínálati elemek lehetnek: fürdős szolgáltatások, szaunák, masszázs és egyéb közérzetjavító terápiák, sportprogramok, beauty szolgáltatások, közösségi programok és reformgasztronómia, mely az egészség holisztikus megközelítése értelmében alkalmas az egészség megőrzésére, megtartására (Müller et al., 2005; Borbély-Müller 2008; Könyves et al., 2013; Müller et al., 2013; Müller et al., 2017).

A wellness elemek kitolják a szezont, növelhetik a vendégek tartózkodási idejét ezzel költéshajlandóságát és nagyobb bevételeket generálnak a szolgáltatók számára és nagyobb realizált üzleti eredményt is, mely a beruházások megtérülésében szerepet játszik (Könyves et al., 2013).

A beruházás időintervalluma azonos, 2014-2015 közötti időszak. Jelentős különbség tapasztalható a felvett hitel mennyiségére, valamint a hitel futamidejére, THM-jére vonatkozóan. Az „A” vállalat jóval magasabb összeget vett fel, kedvezőtlenebb feltételek mellett. 


\section{A vizsgálat eredményei}

A beruházások befejeződése után, 3 éven keresztül, egészen 2017-ig vizsgáltam a bevételek és a ráfordítások alakulását „A” és „B” vállalat esetén. Az eredményeket a 6. táblázat tartalmazza.

\begin{tabular}{|l|c|c|c|c|c|c|}
\hline \multirow{2}{*}{ Megnevezetés } & \multicolumn{2}{|c|}{ „A” vállalat } & \multicolumn{3}{c|}{ „B” vállalat } \\
\cline { 2 - 7 } & $\mathbf{2 0 1 5}$ & $\mathbf{2 0 1 6}$ & $\mathbf{2 0 1 7}$ & $\mathbf{2 0 1 5}$ & $\mathbf{2 0 1 6}$ & $\mathbf{2 0 1 7}$ \\
\hline Szálláshelyadásból származó bevételek változása & $28 \%$ & $17 \%$ & $10 \%$ & $39 \%$ & $28 \%$ & $20 \%$ \\
\hline Vendéglátásból származó bevételek változása & $26 \%$ & $13 \%$ & $7 \%$ & $31 \%$ & $25 \%$ & $18 \%$ \\
\hline Egyéb szolgáltatásokból származó bevételek változása & $25 \%$ & $10 \%$ & $6 \%$ & $20 \%$ & $20 \%$ & $15 \%$ \\
\hline Bevételek összesített változása & $27 \%$ & $16 \%$ & $9 \%$ & $35 \%$ & $26 \%$ & $19 \%$ \\
\hline Ráfordítások változása & $15 \%$ & $17 \%$ & $20 \%$ & $10 \%$ & $11 \%$ & $9 \%$ \\
\hline
\end{tabular}

6. táblázat: „A” és „B” vállalat bevételeinek és ráfordításainak százalékos változása 2015-2017. év között Forrás: (Saját készítésű táblázat a vállalatok beszámolói, kitöltött kérdőívei alapján)

A vizsgált időszakban mindkét vállalat bevételei növekedtek szálláshelyadás, vendéglátás és egyéb szolgáltatásokból származó bevételek esetén egyaránt. A „B” vállalat esetében azonban a beruházás megvalósulása után, 2014-ről 2015-re nagyobb mértékű (+8\%-kal), 35\%-os növekedés tapasztalható. A legnagyobb mértékű növekedéskülönbség a szálláshelyadásból származó bevételeket érinti, a „B” vállalat majdnem 40\%-os növekedést tudott elérni 2014-hez viszonyítva. Jelentős a bevétel növekedés a vendéglátásból és az egyéb szolgáltatásból származó bevételek esetén is, még a 2016-ról 2017-re történő növekedés is majdnem elérte a $20 \%$-ot. $\mathrm{Az}$ „A” vállalat ezzel szemben ebben az időszakban $10 \%$ alatti növekedést ért el. A bevételek összegszerű változása alapján megállapítható továbbá, hogy az „A” vállalat esetén az egyes bevételek aránya az összbevételen belül nem változott jelentősen 20152017 között, a szálláshelyadásból származó bevételek aránya 60\% körüli, a vendéglátásból származó bevételek aránya 30\% körüli, míg az egyéb szolgáltatásból származó bevételek aránya 10\% alatti maradt. Ezzel szemben a „B” vállalat esetén folyamatos arányeltolódás volt megfigyelhető a vendéglátás és az egyéb szolgáltatásból származó bevételek javára.

A ráfordítások természetesen a jelentős bevétel növekedések révén szintén azonos irányban változtak, azonban az „A" vállalat esetén átlagosan egy 17\%-os növekedés volt tapasztalható, míg a „B” vállalat esetén az átlagos ráfordítás növekedés a vizsgált időszakban $10 \%$-os volt.

A bevételek és ráfordítások alakulásakor megfigyelhető tendenciák a jövedelmezőségi mutatók alakulását is determinálták. A „B” vállalat jövedelmezősége jóval kedvezőbb. A mutatók alakulását a 7. táblázat szemlélteti. 


\begin{tabular}{|c|c|c|c|c|c|c|}
\hline \multirow{2}{*}{ Mutatók megnevezése } & \multicolumn{3}{|c|}{ "A" vállalat } & \multicolumn{3}{c|}{ "B" vállalat } \\
\cline { 2 - 7 } & 2015 & 2016 & 2017 & 2015 & 2016 & 2017 \\
\hline ROS (ÜTE) & $6,20 \%$ & $4,20 \%$ & $-2,50 \%$ & $15,00 \%$ & $33,00 \%$ & $37,00 \%$ \\
\hline ROS (Adózott eredmény) & $1,70 \%$ & $0,50 \%$ & $-7,10 \%$ & $22,00 \%$ & $29,00 \%$ & $34,00 \%$ \\
\hline ROE (ÜTE) & $1,50 \%$ & $1,20 \%$ & $-1,00 \%$ & $12,50 \%$ & $17,10 \%$ & $18,00 \%$ \\
\hline ROE (Adózott eredmény) & $0,50 \%$ & $0,10 \%$ & $-3,00 \%$ & $10,00 \%$ & $13,40 \%$ & $14,70 \%$ \\
\hline
\end{tabular}

7. táblázat: Jövedelmezőségi mutatók százalékos változása 2015-2017. év között

Forrás: (Saját készítésú táblázat a vállalatok éves beszámolói alapján)

$\mathrm{Az}$ „A" vállalat már a beruházást megelőző időszakban is alacsonyabb bevétellel és magasabb költséghányaddal rendelkezett, ezáltal természetesen alacsonyabb értékű jövedelmezőségi mutatókkal is. Bármely jövedelmezőségi mutatót tekintjük, ugyanaz a konzekvencia vonható le, hiába rendelkezik a vállalat megfelelő szintű bevétellel és képes biztosítani a bevételeinek dinamikus növekedését, ha emellett a felmerülő költségek szintje is magas, sőt a bevételeket meghaladó mértékben növekedik. Az adózott eredményt figyelembe vevő jövedelmezőségi mutatók értéke még kedvezőtlenebb, ami a pénzügyi tevékenység nem megfelelő eredményességére utal.

A „B” vállalat jövedelmezőségi mutatói jóval kedvezőbbek, kiemelkedő jövedelem előállító képességgel rendelkezik, a bevételek emelkedése, valamint a ráfordítások alacsonyabb mértékű növekedése a mutatók további emelkedését eredményezte. Az adózott eredményt figyelembe vevő mutatók értéke azonban alacsonyabb, ami a pénzügyi tevékenység veszteségességére utal.

\section{Következtetések, összegzés}

A „B” vállalat jövedelmezősége kiemelkedő, bevételei dinamikusan növekedtek valamennyi tevékenység vonatkozásában, a bevétel növekedés mértéke jóval meghaladta a ráfordítások növekedésének mértékét, 2017-ben a ROS (ÜTE) értéke már 37\%, ROE (ÜTE) értéke pedig 17\%. Véleményem szerint a jövedelmezőség emelkedése a támogatás sikeres felhasználásra vezethető vissza, a szolgáltatások minőségének emelése során érvényesülő komplex szemléletre. Nem csak az éttermi szolgáltatást fejlesztették, hanem hangsúlyt fektettek a wellness részleg színvonalának emelésére is, számos új szolgáltatást vezettek be. A marketing költségek alakulásából továbbá arra lehet következtetni, hogy a vállalat tudatában van annak, hogy e tevékenység a versenyképességre nagymértékben hatással van. Képes hatékony költséggazdálkodás folytatására, gondosan választja ki a beszállítóit, a jó ár/érték arány elsődleges. A személyi jellegű költségeket is megfelelő kontrol alatt képes tartani, a dolgozók jelentős hányada munkaügyi központon keresztül kerül a vállalathoz, jelentős bér és járulékkedvezményekkel. Mindezek mellett a beruházáshoz megfelelő hitelkonstrukciót választott a cég, mely rövid távon, viszonylag alacsony kamatterhet jelent.

A „A” vállalat jövedelmezősége nem tekinthető megfelelőnek, bár bevételei dinamikusan növekedtek valamennyi tevékenység vonatkozásában, a ráfordítások növekedésének mértéke meghaladta a bevételek növekedésének mértékét. 2017-ben valamennyi jövedelmezőségi mutató negatív értéket vett fel. A jövedelmezőség ilyen mértékű romlása a támogatás nem megfelelő felhasználásával is kapcsolatba hozható, a szolgáltatások minőségének emelése során nem érvényesült komplex 
szemlélet. Csak az éttermi szolgáltatást fejlesztették, esetenként túl sokat költve szükségtelen, csak többletkiadást eredményező változtatásokra. Nem mérték fel a wellness részleg modernizációjának, a szolgáltatások vendég-központibbá tételének szükségességét. A magas költséghányad továbbá arra utal, hogy a vállalat nem képes hatékony költséggazdálkodás folytatására, anyag és személyi jellegű költségei is túlzottan magasak. Míg a „B” vállalat számos foglalkoztatási támogatást vett igénybe, addig az „A” vállalat egyáltalán nem. A mutatók adózott eredményt figyelembe vevő változatai még kedvezőtlenebb képet mutatnak, mivel a vállalat nagy arányú, kedvezőtlenebb konstrukciójú hitelfelvétel mellett valósította meg a beruházását, ezáltal éves szinten jóval magasabb kamatteherrel szembesült, pénzügyi múveleteinek eredményei tovább rontották a jövedelmezőséget.

\section{Hivatkozások}

[1] J. Diamond (1977) Tourism's role in economic development: The case re-examined. Economic Development \& Cultural Change, 25 (3) pp. 539-553.

[2] G. Fazakas - B. Gáspár - R. Soós (2009) Bevezetés a pénzügyi és vállalati pénzügyi számításokba. Tanszék Kft. Kiadó, Budapest. 664. p.

[3] E. Kerényi - A. Müller - E. Könyves - I. Lázárné Fodor - A. Mosonyi (2010a) Turisztikai márka és termékfejlesztés lehetôségei az egészségturizmusban az Észak-magyarországi és az Északalföldi régiókban. Acta Academiae Agriensis, 37 pp. 67-73.

[4] F-né Kondorosi (2002) A vezetói számvitel és alapjai. RÉGIÓ Oktatási Központ Kft., Debrecen. 140. p.

[5] E. Könyves - A. Müller - A. Mondok (2004) Az egészségturizmus lehetőségei Hajdúszoboszló példáján. In: VIII. Szolnoki Tudományos Közlemények (cd)., Szolnoki Tudományos Napok. Városháza. Magyarország, Szolnok.

[6] E. Könyves - A. Müller - F. Szalay - R. Szabó (2005) Cserkeszőlő és Karcag egészségturizmusának összehasonlító elemzése. In: Szolnoki Tudományos Közlemények IX. (cd) 2005. A Magyar és a Világ tudomány napja. Városháza. Magyarország, Szolnok. pp. 2-9.

[7] N. Kulendran - K. Wilson (2000) Modelling Business Travel. Tourism Economics, 6 (1) pp. 4759.

[8] N. Leiper (1993) Industrial entropy in tourism systems. Annals of Tourism Research, 20 (1) pp. 221-226.

[9] A. Mosonyi - A. Lengyel - A. Müller (2013) Branding potential of spas in the Northern Plain and the Mid-Transdanubian Regions. Apstract - Applied Studies in Agribusiness and Commerce 74 (5) pp. 97-101.

[10] A. Müller - E. Könyves (2006) Az egészségturizmus lehetôségei az Észak-alföldi régióban. Acta Academiae Pedagogicae Agriensis - Az Eszterházy Károly Főiskola tudományos közleményei. 33 pp. 132-144

[11] A. Müller - V. Kórik (2009) Az Észak-alföldi fürdók szerepe a turizmusban és a rekreációban. Economica, 2 pp. 58-72

[12] K. Przeclawski (1993) Tourism as the Subject of Interdisciplinary Research. Tourism Research: Critiques and Challenges. London, pp. 9-19.

$\mathrm{I}_{1}$ : KSH (2016): Jelentés a turizmus és vendéglátás 2016. évi teljesítményéről.

http://www.ksh.hu/docs/hun/xftp/idoszaki/jeltur/jeltur16.pdf 
$\mathrm{I}_{2}$ : EUROSTAT (2016):Tourism trips of residents (aged 15 years or more), 2016

http://ec.europa.eu/eurostat/statistics-

explained/index.php?title=File:Tourism_trips_of_residents_(aged_15_years_or_more),2016.png\&oldid $=368939$

I 3 : EUROSTAT (2016) Tourist accommodation establishments, 2016

http://ec.europa.eu/eurostat/statistics-

explained/index.php?title=File:Tourist_accommodation_establishments,_2016.png\&oldid=368940

I 4 : EU Pályázatok (2012): Észak-Alföldi Operatív Program. Akcióterv

https://www.palyazat.gov.hu/doc/2670 